Please do not remove this page

RMIT

UNIVERSITY

\title{
Initial crystallisation or nucleation in a liquid aluminium alloy containing spinel seeds
}

Haghayeghi, R.; Qian, Ma

https://researchrepository.rmit.edu.au/esploro/outputs/9921860606601341/filesAndLinks?institution=61RMIT_INST\&index=null

Haghayeghi, R., \& Qian, M. (2017). Initial crystallisation or nucleation in a liquid aluminium alloy containing spinel seeds. Materials Letters, 196, 358-360. https://doi.org/10.1016/j.matlet.2017.03.083

Document Version: Accepted Manuscript

Published Version: https://doi.org/10.1016/j.matlet.2017.03.083

Repository homepage: https://researchrepository.rmit.edu.au

(C) 2017 Elsevier B.V. All rights reserved.

Downloaded On 2023/04/27 00:46:41 +1000

Please do not remove this page 
Thank you for downloading this document from the RMIT Research Repository.

The RMIT Research Repository is an open access database showcasing the research outputs of RMIT University researchers.

RMIT Research Repository: http://researchbank.rmit.edu.aul

\section{Citation:}

Haghayeghi, R and Qian, M 2017, 'Initial crystallisation or nucleation in a liquid aluminium alloy containing spinel seeds', Materials Letters, vol. 196, pp. 358-360.

See this record in the RMIT Research Repository at:

https://researchbank.rmit.edu.au/view/rmit:44714

Version: Accepted Manuscript

\section{Copyright Statement:}

(c) 2017. This manuscript version is made available under the CC-BY-NC-ND 4.0 license http://creativecommons.org/licenses/by-nc-nd/4.0/

Link to Published Version:

https://dx.doi.org/10.1016/j.matlet.2017.03.083 


\title{
Initial crystallisation in a liquid aluminium alloy containing spinel seeds
}

\author{
R. Haghayeghi ${ }^{1, *}$ and M. Qian ${ }^{2}$
}

1. Department of Materials Engineering, Science and Research Branch, Islamic Azad University, Tehran, Iran.

2. RMIT University, School of Engineering, Centre for Additive Manufacturing, Melbourne, VIC 3000, Australia

*Corresponding author, E-Mail:rhaghayeghi@gmail.com, Tel: +98 9128241380

\begin{abstract}
Step-by-step in-situ near-atomic-resolution observations were presented for initial crystallization in a liquid $\mathrm{Al}-10 \mathrm{Mg}$ (wt.\%) alloy containing spinel $\left(\mathrm{MgAl}_{2} \mathrm{O}_{4}\right)$ seeds. Ordering of $\mathrm{Al}$ atoms was observed in the alloy at the interface with spinel at the superheat of $73^{\circ} \mathrm{C}$ or $680^{\circ} \mathrm{C}$, where three ordered layers of $\mathrm{Al}$ atoms formed and disappeared alternately. When cooled to the approximate liquidus of the alloy, $607^{\circ} \mathrm{C}$, three similar but more stable ordered layers of $\mathrm{Al}$ atoms formed. Subsequent crystallization occurred first through the formation of partially close-packed $\mathrm{Al}$ atoms on the solid-like outer ordered layer of Al atoms, followed by further crystallization into more close-packed $\mathrm{Al}$ atoms.
\end{abstract}

Keywords: Solidification; Solid-liquid interface; Epitaxial growth

\section{Introduction}

Theoretical studies have predicted that at a liquid metal-solid interface, there should exist a transition of a solid-like phase (e.g., ordered layers) that is typically a few atomic layers thick [1], and this interfacial layer is expected to affect the subsequent 
crystallisation. To date, only limited experimental evidence is available due to challenges of detecting the ordering process in liquid metals. Arai, Saka and coworkers [2-5] first reported partially ordered $\mathrm{Al}$ atoms at liquid-AI-droplet/solid-Siparticle interfaces via in-situ high-resolution transmission electron microscopy (HRTEM). However, it was unclear if the liquid Al droplets were superheated or supercooled. Also, no information was given about the subsequent evolution of the ordered Al atoms on cooling. Oh et al. [6] observed ordered Al atoms at the liquid$\mathrm{Al} / \mathrm{Al}_{2} \mathrm{O}_{3}$ interfaces at $\sim 750^{\circ} \mathrm{C}$ using in-situ HRTEM, where $\mathrm{Al}_{2} \mathrm{O}_{3}$ is known to be an ineffective nucleant for Al [7]. Similarly, they did not show the evolution of the ordered Al atoms on cooling. The link between ordering and subsequent crystallisation therefore remains unclear.

This study applied in-situ HRTEM observations to the interface between a liquid $\mathrm{Al}-10 \mathrm{Mg}$ (wt.\%) alloy and $\mathrm{MgAl}_{2} \mathrm{O}_{4}$ at both $680^{\circ} \mathrm{C}$ and the approximate liquids of the alloy, $607^{\circ} \mathrm{C}$. We focused on capturing instant structural changes in order to provide some first-hand experimental evidence for initial crystallisation. $\mathrm{MgAl}_{2} \mathrm{O}_{4}$ was chosen because it is a potent nucleant for $\mathrm{Al}[8-10]$ and is more relevant to industry practices.

\section{Experimental procedure}

A $2.5-\mathrm{kg} \mathrm{Al}-10 \% \mathrm{Mg}$ melt was prepared from $\mathrm{Al}(99.96 \%)$ and $\mathrm{Mg}(99.97 \%)$ ingot materials in a $\mathrm{BN}$-coated steel crucible at $700^{\circ} \mathrm{C}$ under argon. $\mathrm{MgAl}_{2} \mathrm{O}_{4}$ is more stable at this temperature than $\mathrm{MgO}$ [11]. Since $\mathrm{MgAl}_{2} \mathrm{O}_{4}$ tends to form as patches, ultrasonic vibration $(17.5 \mathrm{KHz})$ was applied to the melt sub-surface at $680^{\circ} \mathrm{C}$ for $60 \mathrm{~s}$ to disperse $\mathrm{MgAl}_{2} \mathrm{O}_{4}$ into the melt, which was then cast into $40 \mathrm{~mm}$ diameter bars in a water-cooled BN-coated steel mould. Disc samples of $3 \mathrm{~mm}$ in diameter were cut from the ingot and thinned to $\sim 50 \mu \mathrm{m}$ mechanically. They were then ion-beam- 
thinned using a Gatan precision ion polishing system for typical TEM characterization.

A JEM-ARM 1250 ultrahigh-voltage HRTEM system was used for in-situ observations. The system was operated at 1.25 MV and equipped with side-entry objective lenses to achieve a resolution of $0.12 \mathrm{~nm}$. Heating was achieved through an automatic closed-loop temperature controller that surrounds the membrane which monitors and regulates the temperature. The membrane material minimises the heat loss during heating to ensure high-resolution observations at a specified temperature within $\pm 1^{\circ} \mathrm{C}$. In-situ observations were recorded using a special high-resolution camera in the system which takes pictures at an interval of $4 \mathrm{~ms}$.

The foil samples used were $\sim 3 \mathrm{~mm}$ in diameter and $\sim 100 \mathrm{~nm}$ thick. Two samples were prepared. The first was used to test the planned in-situ observations at both $680^{\circ} \mathrm{C}$ and $607^{\circ} \mathrm{C}$ including calibration, followed by the second formal test. In each test, the sample was placed on the membrane with an identified $\mathrm{MgAl}_{2} \mathrm{O}_{4}$ particle being set in focus. The temperature was first raised to $680^{\circ} \mathrm{C}$ in a second and then kept constant to observe changes at the interface. Following observations at $680^{\circ} \mathrm{C}$, the temperature was lowered from $680^{\circ} \mathrm{C}$ to $607^{\circ} \mathrm{C}$ at $15^{\circ} \mathrm{C} / \mathrm{s}$ and held at $607^{\circ} \mathrm{C}$ for similar observations.

\section{Results and discussion}

Fig. 1 shows the TEM characterization results of an $\alpha-A \mathrm{l} / \mathrm{MgAl}_{2} \mathrm{O}_{4}$ interface observed in the Al-10Mg alloy at room temperature (RT). A flat and coherent interface with one atomic layer thickness of $193 \mathrm{pm}$ was identified, Fig. 1(a). In addition, Al and $\mathrm{MgAl}_{2} \mathrm{O}_{4}$ exhibited a cube-on-cube orientation relationship (Fig. 1(b)), characterised to be (100) [001] $\mathrm{MgAl}_{2} \mathrm{O}_{4} / /(100)$ [001] $\alpha$-Al. Both observations agree with Refs. [8- 
10] and support the conclusion that $\mathrm{MgAl}_{2} \mathrm{O}_{4}$ is a potent nucleant for Al. Similar to the simulation results obtained by using EMAPS [12], (020)s is invisible in Fig. 1(b). In addition, no $\mathrm{Mg}$ atoms were detected at the interface. The influence of $\mathrm{Mg}$ on interfacial crystallization will be reported in another study.
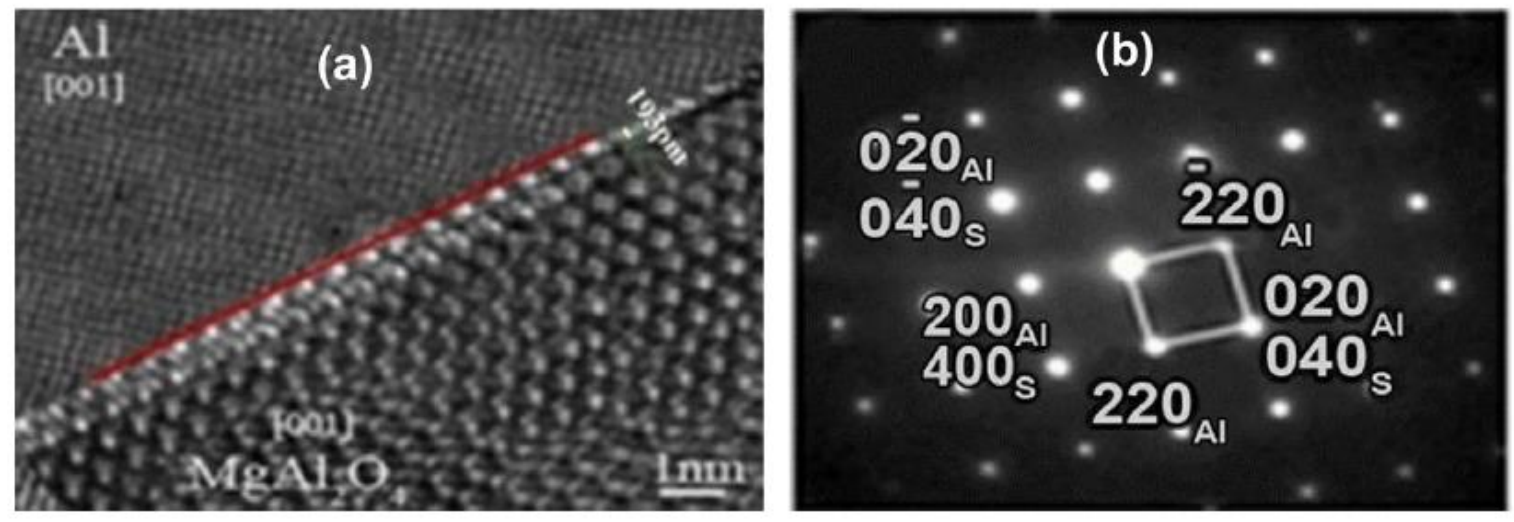

Figure 1 (a) TEM bright field image showing a coherent $\alpha-\mathrm{Al} / \mathrm{MgAl}_{2} \mathrm{O}_{4}$ interface in assolidified Al-10Mg at room temperature. (b) SAED patterns of $\mathrm{MgAl}_{2} \mathrm{O}_{4}$ and $\alpha-\mathrm{Al}$ along [001] direction, consistent with Ref. [8-10].

Subsequent in-situ HRTEM observations were focused on structural changes at a selected $\alpha-\mathrm{Al} / \mathrm{MgAl}_{2} \mathrm{O}_{4}$ interface when heated to $680^{\circ} \mathrm{C}$ from $\mathrm{RT}$. As shown in Fig. 2, the following observations were notable:

- An atomically flat interface was observed on reaching $680{ }^{\circ} \mathrm{C}$ which distinguished the solid $\mathrm{MgAl}_{2} \mathrm{O}_{4}$ substrate from the liquid, Fig. 2(a).

- Three nearly parallel ordered layers of Al atoms were repeatedly observed at the interface despite the large superheat $\left(73^{\circ} \mathrm{C}\right)$ and the first layer showed close contact with $\mathrm{MgAl}_{2} \mathrm{O}_{4}$ by HRTEM, Fig. 2(a, c).

- The interfacial structure was dynamic and unstable; the ordered layers of Al atoms formed and disappeared alternately at regular intervals, Fig. 2(a, b, c). 
It took about $8 \mathrm{~ms}$ for them to form and became no longer visible by HRTEM in the next 3-4 ms (the survival time).
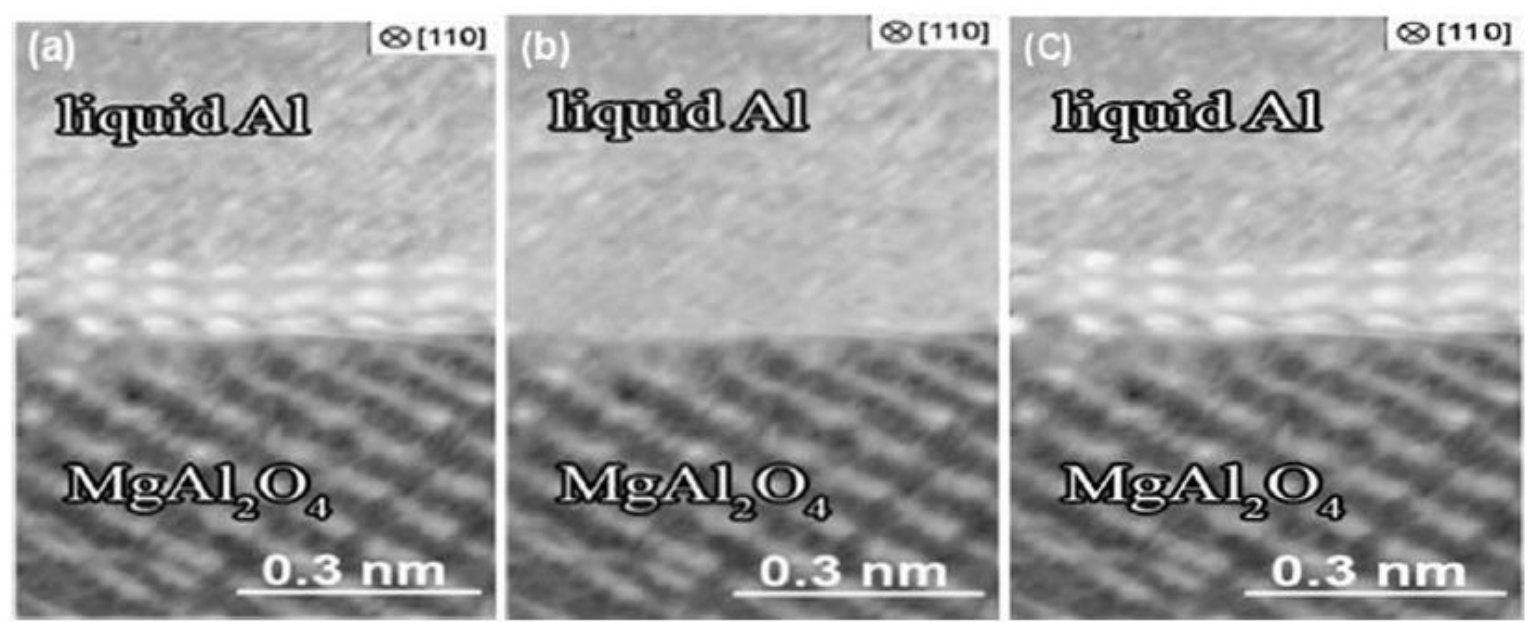

Figure 2 In-situ HRTEM observations of ordering in liquid Al-10Mg at the interface with $\mathrm{MgAl}_{2} \mathrm{O}_{4}$ at $680^{\circ} \mathrm{C}$. (a) $8 \mathrm{~ms}$ after reaching $680^{\circ} \mathrm{C}$; (b) disappearance of ordered layers in $4 \mathrm{~ms}$ following (a); and (c) re-ordering in 8 ms following (b) at the same interface.

The temperature was subsequently decreased from $680^{\circ} \mathrm{C}$ to $607^{\circ} \mathrm{C}$ at $15^{\circ} \mathrm{C} / \mathrm{s}$. When reaching $607^{\circ} \mathrm{C}$, three ordered layers of $\mathrm{Al}$ atoms, analogous to those shown in Fig. 2(a, c), were observed. In contrast to $680^{\circ} \mathrm{C}$, the ordered layers of $\mathrm{Al}$ atoms remained stable at $607^{\circ} \mathrm{C}$ during the next 36 ms until abrupt crystallization occurred from the solid-like outer ordered layer of Al atoms into the liquid. Fig 3(a) shows such newly crystallized $\mathrm{Al}$ atoms captured at the $36^{\text {th }} \mathrm{ms}$ at $607^{\circ} \mathrm{C}$. These newly crystallized Al atoms were stable until they unexpectedly transformed into a more close-packed state, as shown in Fig. 3(b). This transition revealed that the initially crystallized Al atoms shown in Fig. 3(a) just rearranged themselves into a 'partially crystallized' state rather than a fully crystallized state. It can be an easier 
pathway for a liquid to crystallize through an intermediate 'partially crystallized' state due to the smaller driving force required. The newly crystallized Al atoms exhibited a different growth direction, which has presumably offered a low energy pathway for solidification to occur.
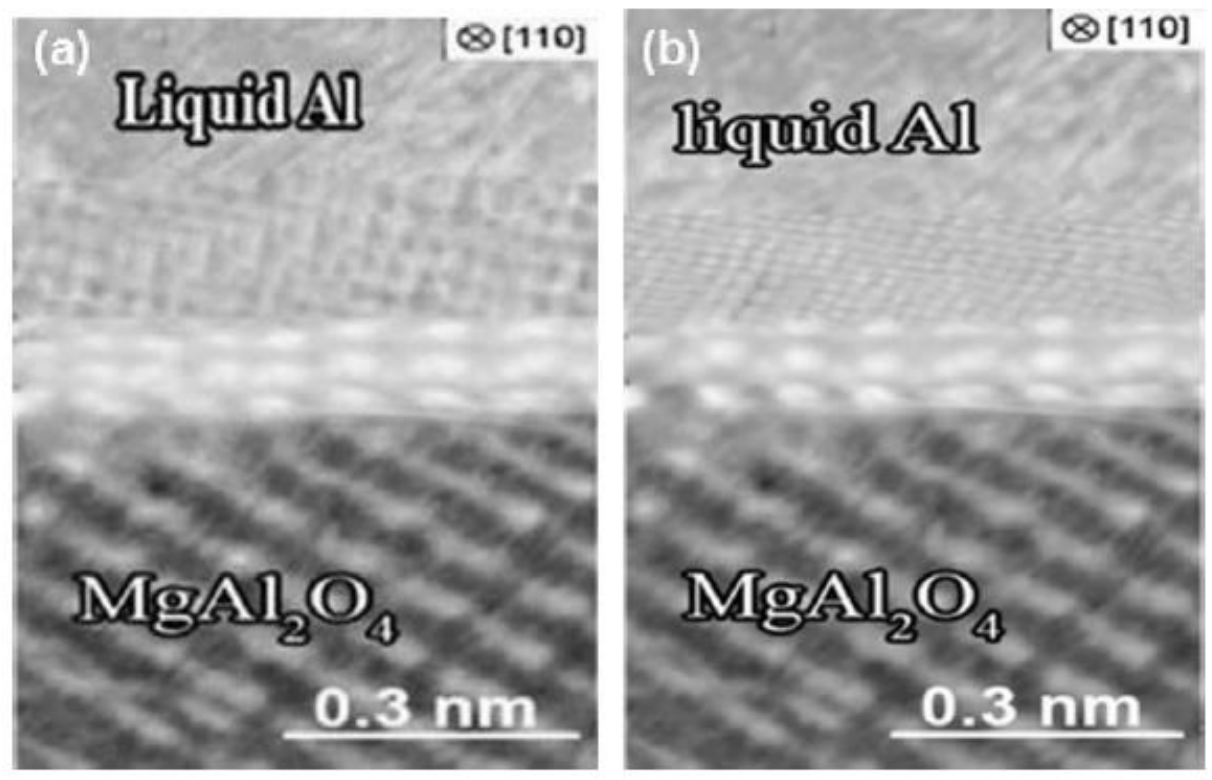

Figure 3 Ordering and subsequent crystallization at $607^{\circ} \mathrm{C}$. (a) Ordered layers formed at $607^{\circ} \mathrm{C}$ and were stable for $36 \mathrm{~ms}$ until crystallization occurred from the outer ordered layer. (b) The partially crystallized Al atoms in (a) changed to a more close-packed state in the next $8 \mathrm{~ms}$.

It was noted from Figs. 2 and 3 that the bright spots are only $\sim 0.05 \mathrm{~nm}$ in size, which is much smaller than an Al atom (0.236 nm at RT [13]). We believe that each bright spot captured during in-situ HRTEM observations represents only part of an Al atom, rather than the largest cross-section of the $\mathrm{Al}$ atom. This appears to be 
reasonable due to the high vibration frequency of $\mathrm{Al}$ atoms at the observation temperatures $\left(680^{\circ} \mathrm{C}\right.$ or $\left.607^{\circ} \mathrm{C}\right)$.

The driving force for ordering at the interfacial liquid can be attributed to the work of adhesion $\left(W_{\mathrm{SL}}\right)$ [14], described by the Young-Dupré equation through $W_{\mathrm{SL}}=$ $\gamma_{L}(1+\cos \theta)$, where $\theta$ is contact angle and $\gamma_{L}$ is surface tension [14]. The value of $W_{S L}$ for a ceramic-metal contact is typically in the order of $1 \mathrm{~J} \mathrm{~m}^{-2}$ [15]. The contribution of wetting to $W_{S L}$ for a liquid metal-ceramic contact has been discussed in detail [15, 16]. Only chemical wetting, i.e., the electrostatic forces including the ionic type, can give a work of adhesion in the order of $1 \mathrm{~J} \mathrm{~m}^{-2}$ between ceramics and metals. For adhesion of metals to ionic ceramics such as $\mathrm{Al}$ to $\mathrm{MgAl}_{2} \mathrm{O}_{4}$, the image interaction can give the order of $1 \mathrm{~J} \mathrm{~m}^{-2}$ if ions are treated as point charges [16].

Taking the typical value of $1 \mathrm{~J} \mathrm{~m}^{-2}$ for $W_{\mathrm{SL}}$, the work of adhesion arising from $\mathrm{MgAl}_{2} \mathrm{O}_{4}$ is equivalent to applying a force of adhesion of $10^{-6} \mathrm{~N} \mathrm{\mu m^{-1 }}$ to the interfacial liquid of $\mathrm{Al}$ along the length or width direction of the substrate. This force of adhesion changes the packing of $\mathrm{Al}$ atoms in the interfacial liquid but it is still insufficient to entail full crystallization of the liquid $\mathrm{Al}$ atoms compared to the latent heat of fusion of $\mathrm{Al}\left(10.7 \mathrm{~kJ} \mathrm{~mol}^{-1}\right.$ [17]). A greater work of adhesion is required for close-packed Al atoms to form or crystallisation of liquid Al atoms to occur at the substrate surface. The effect of $W_{S L}$ is short-ranged, which becomes less significant from about three atomic layers away from the interface at both $680^{\circ} \mathrm{C}$ and $607^{\circ} \mathrm{C}$ (Figs. 2 and 3).

The formation and disappearance of ordered layers of Al atoms are a result of the battle between $W_{S L}$ (ordering) and the mobility of liquid Al atoms (disordering), both being temperature dependent. In that regard, the spacing between the ordered layers may be treated as a measure of $W_{\mathrm{SL}}$. The surface tension of molten $\mathrm{Al}$ 
decreases with increasing temperature [18]. Accordingly, the driving force $\left(W_{\mathrm{SL}}\right)$ for ordering will decrease but not significantly. Hence the observations shown in Fig. 2 are also expected to occur at other temperatures around $680^{\circ} \mathrm{C}$.

\section{Summary}

- Ordering of $\mathrm{Al}$ atoms was observed at the superheat of $\sim 73^{\circ} \mathrm{C}$ or $680^{\circ} \mathrm{C}$ in $\mathrm{Al}-$ $10 \mathrm{Mg}$ at the interface with $\mathrm{MgAl}_{2} \mathrm{O}_{4}$

- The ordered layers of $\mathrm{Al}$ atoms that formed at $680^{\circ} \mathrm{C}$ were unstable; they formed and disappeared alternately at $680^{\circ} \mathrm{C}$.

- The ordered layers of $\mathrm{Al}$ atoms that formed at the liquidus of the alloy $\left(607^{\circ} \mathrm{C}\right)$ were relatively stable and entailed subsequent crystallisation, which occurred first through forming partially close-packed Al atoms from the solid-like outer ordered layer of $\mathrm{Al}$ atoms and then through further crystallisation into a more close-packed state.

\section{Acknowledgements}

The authors thank the support of contributing Research Centres. M. Qian acknowledges the support of ARC DP140100702.

\section{References}

[1] A. Hashibon, J. Adler, M.W. Finnis, W.D. Kaplan, Comput. Mater. Sci., 24 (2002) $443-452$.

[2] S. Arai, S. Tsukimoto, H. Miyai and H. Saka, J. Electron Microscopy, 48 (1999) 317-321.

[3] S. Arai, S. Tsukimoto, S. Muto \& H. Saka. Microscopy and Microanalysis, 6 (2000) 358-361.

[4] H. Saka, K. Sasaki, S. Tsukimoto \& S. Arai, J. Mater. Res., 20 (2005) 1629-1640. 
[5] J.M. Howe, H. Saka, MRS. Bull., 29 (2004) 951-957.

[6] S.H. Oh, Y. Kauffmann, C. Scheu, W.D. Kaplan, M. Ruehle, Science, 310 (2005) 661-663.

[7] B.A. Mueller, J. H. Perepezko, Met. Trans. A, 18 (1987) 1143-1152.

[8] Y. Wang, H.T. Li, Z. Fan, Trans. Indian Inst. Met., 65 (2012) 653-661.

[9] H.T. Li, Y. Wang, Z. Fan, Acta Mater., 60 (2012) 1528-1537.

[10] R. Schweinfest, S. Kostlmeier, F. Ernst, C. Elsasert, T. Wagner, M.W. Finnis, Phil Mag, 81(4) (2001) 927-955.

[11] I. Haginoya, T. Fukusako, Trans. Japan Inst. Metals, 24(9) (1983) 613-619

[12] J. M. Zuo, J. C. Mabon, Microsc Microanal 10 (Suppl 2) (2004) 1000-1001.

[13] http://periodictable.com/Properties/A/AtomicRadius.v.html

[14] M.W. Finnis, J. Phys.: Condens. Matter 8 (1996) 5811-5836.

[15] Y.V. Naidich, Y.N. Chubashov, N.F. Ishchuk, V.P. Krasovskii, Powder Metall Met Ceram, 22 (1983) 481-483.

[16] D. M. Lipkin, J. N. Israelachvili \& D.R. Clarke, Phil Mag A, 76 (1997) 715-728

[17] http://periodictable.com/Elements/013/data.html

[18] B.J. Keene, Int. Mater. Rev. 38 (1993) 157-192.

\section{Figures and figure captions}

Figure 1 (a) TEM bright field image showing a coherent $\alpha-A \mathrm{I} / \mathrm{MgAl}_{2} \mathrm{O}_{4}$ interface in assolidified $\mathrm{Al}-10 \mathrm{Mg}$ at room temperature. (b) SAED patterns of $\mathrm{MgAl}_{2} \mathrm{O}_{4}$ and $\alpha-\mathrm{Al}$ along [001] direction, consistent with Ref. [8-10].

Figure 2 In-situ HRTEM observations of ordering in liquid Al-10Mg at the interface with $\mathrm{MgAl}_{2} \mathrm{O}_{4}$ at $680^{\circ} \mathrm{C}$. (a) $8 \mathrm{~ms}$ after reaching $680^{\circ} \mathrm{C}$; (b) disappearance of ordered 
layers in $4 \mathrm{~ms}$ following (a); and (c) re-ordering in $8 \mathrm{~ms}$ following (b) at the same interface.

Figure 3 Ordering and subsequent crystallization at $607^{\circ} \mathrm{C}$. (a) Ordered layers formed at $607^{\circ} \mathrm{C}$ and were stable for $36 \mathrm{~ms}$ until crystallization occurred from the outer ordered layer. (b) The partially crystallized Al atoms in (a) changed to a more close-packed state in the next $8 \mathrm{~ms}$. 